\title{
Differential Scanning Calorimetric Analysis of Ni Doped Sodium Hexa-titanate
}

\author{
NAVSHAD ALAM ${ }^{1}$, VISHAL SINGH CHANDEL ${ }^{2 *}$ and TAHIRA KHATOON ${ }^{3}$ \\ ${ }^{1}$ Department of Applied Science, BNCET, Lucknow-226201, India. \\ ${ }^{2}$ Department of APSH, Rajkiya Engineering College, Ambedkar Nagar-224122, India. \\ ${ }^{3}$ Department of Physics, Integral University, Lucknow-226026, India. \\ *Corresponding author E-mail: chandel.integral@gmail.com
} http://dx.doi.org/10.13005/ojc/360423

(Received: March 29, 2020; Accepted: July 25, 2020)

\begin{abstract}
Pure and nickel doped alkali titanates $\mathrm{Na}_{2} \mathrm{Ti}_{6-\mathrm{x}} \mathrm{Ni}_{\mathrm{x}} \mathrm{O}_{13}$ (where $\mathrm{x}=0,0.04,0.08,0.12 \mathrm{~mol}$ percentage) were synthesized using conventional solid-state reaction method. Phase of the synthesized samples have been confirmed with the help of X-ray diffraction (XRD) patterns recorded at room temperature (RT). Peak positions of all samples $\left(\mathrm{Na}_{2} \mathrm{Ti}_{6-x} \mathrm{Ni}_{x} \mathrm{O}_{13}\right)$ exhibited the monoclinic structure. FE-SEM of these samples has been done at $10 \mathrm{kV}$ acceleration voltage, in secondary electron mode, at different magnifications to observe morphology (microstructure) and they have been found as rod shaped. Thermal stability of pure and nickel doped titanates was done with the help of differential scanning calorimetry (DSC) in presence of inert gas (nitrogen) from ambient temperature to $800^{\circ} \mathrm{C}$, keeping heating and cooling rates $10^{\circ} \mathrm{C} /$ minute.
\end{abstract}

Keywords: Alkali titanates, XRD, Monoclinic, Sodium Hexa-titanate, DSC, FE-SEM.

\section{INTRODUCTION}

The common chemical formula of sodium (alkali) titanates is $\mathrm{Na}_{2} \mathrm{Ti}_{\mathrm{n}} \mathrm{O}_{2 \mathrm{n}+1}$ (where $1 \leq n \leq 8)$ [for $1 \leq n \leq 2$, they have layered structure and for $n>2$, they have tunnel type of structure]. Titanates have been explored a lot for various technological applications such as ion exchangers in the industry, electrodes for secondary batteries, reinforcement materials, filters, catalysts, heat insulators etc. as their properties can easily be tailored $^{1-8}$. Kikkawa et al., reported hydrolysis and thermolysis of the alkali titanates, Fujishiro et al., investigated cation exchange property of alkali titanates as these materials are capable in protecting the environment from radioactive wastes, the alkali titanates can also be used as capacitors, electrolyte for fuel cell, biosensors as well as dielectric sensors ${ }^{9-12}$. Study of crystal energy and structure of various alkali titanates $\mathrm{A}_{2} \mathrm{Ti}_{n} \mathrm{O}_{2 n+1}$ $(\mathrm{A}=\mathrm{Li}, \mathrm{Na}, \mathrm{K})$ have been performed by Michele Catti et al., by density functional theory, neutron diffraction, by first-principle calculations and X-ray absorption spectroscopy ${ }^{13}$. Kanchanawarin

This is an Open Access article licensed under a Creative Commons license: Attribution 4.0 International (CC- BY). Published by Oriental Scientific Publishing Company @ 2018

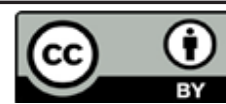


et al., studied oxygen-deficiency in alkali titanates $\mathrm{A}_{2} \mathrm{Ti}_{6} \mathrm{O}_{13}(\mathrm{~A}=\mathrm{Li}, \mathrm{Na}$, and $\mathrm{K})$ and local stoichiometric structure $^{14}$.

Sauvet et al., reported synthesis and thermo gravimetric analysis (TGA) along with differential thermal analysis (DTA) of sodium tri-titanate $\left(\mathrm{Na}_{2} \mathrm{Ti}_{3} \mathrm{O}_{7}\right)$ and hexa-titanate $\left(\mathrm{Na}_{2} \mathrm{Ti}_{6} \mathrm{O}_{13}\right)$. Stengl et al., investigated synthesis, microstructure characterization, photocatalytic activity, thermal analysis of sodium titanate nanorods (DTA-TG of the sample coupled with mass spectroscopy, emanation thermal analysis), Cardoso et al., reported thermal characterization of lamellar titanates $\left(\mathrm{K}_{2} \mathrm{Ti}_{4} \mathrm{O}_{9}\right.$ and $\mathrm{Na}_{2} \mathrm{Ti}_{3} \mathrm{O}_{7}$ ), Umek et al., reported the effect of the temperature on the morphology of one dimensional sodium titanate nanostructures (Sodium Titanate Nanotubes and Nanoribbons) and their thermal stability, Razali et al., reported hydrothermal synthesis, morphological and structural analysis of titanate and titania nanostructures ${ }^{15-19}$. Alkali titanates with tunnel and layered structure have been synthesized by various research groups including our group ${ }^{20-33}$.

\section{MATERIALS}

For synthesis of sodium hexa-titanate (NHT alkali titanate), titanium (IV) oxide $\left(\mathrm{TiO}_{2}\right)$ powder (<100nm, Purity 99.5\%) was purchased from Sigma Aldrich. Sodium carbonate $\left(\mathrm{Na}_{2} \mathrm{CO}_{3}\right.$, Purity $\left.\geq 99.5 \%\right)$ AR grade and nickel oxide (NiO, Purity $\geq 99.5 \%$ ) AR grade were purchased from Thomas Baker.

\section{METHOD}

Addition of sodium carbonate and titanium dioxide $\left(\mathrm{TiO}_{2}\right)$ in a proper molar ratio gives sodium hexa-titanate, detailed synthesis process has already been published ${ }^{4,12}$.

$$
\mathrm{Na}_{2} \mathrm{CO}_{3}+6 \mathrm{TiO}_{2} \rightarrow \mathrm{Na}_{2} \mathrm{Ti}_{6} \mathrm{O}_{13}+\mathrm{CO}_{2} \uparrow
$$

For the preparation of nickel $(\mathrm{Ni})$ doped sodium hexa-titanate $\left(\mathrm{Na}_{2} \mathrm{Ti}_{6-\mathrm{x}} \mathrm{Ni}_{\mathrm{x}} \mathrm{O}_{13}\right)$ for different molar concentration $(x=0.0,0.04,0.08,0.12)$, the equations are given below.

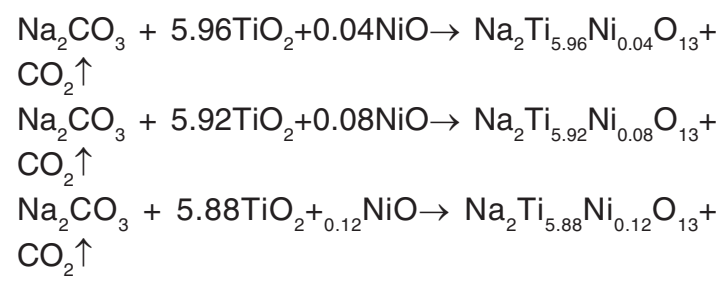

After adding all components, mixture was ground properly for 6 hours. After grinding, mixture was kept in a programmable muffle furnace for 12 $\mathrm{h}$ at $900^{\circ} \mathrm{C}$, the rate of heating was fixed at $4^{\circ} \mathrm{C}$ per minute. After that the mixture was cooled in the furnace itself up to room temperature. The cooled material was again ground for $30 \mathrm{~min}^{12,22-23}$. It was then ready for characterization.

\section{RESULTS AND DISCUSSIONS}

\section{X-ray Diffraction}

Figure 1 represents the X-ray diffraction patterns of pure and nickel doped NHT samples recorded at room temperature, which reveals single phase with monoclinic structure. Non-existence of extra peaks in the XRD pattern confirms the single phase of the samples and successful doping of nickel in sodium hexa-titanate. Lattice parameters of the samples can also be calculated using equation (1) given below.

$$
\frac{1}{d_{\text {hkl }}^{2}}=\frac{h^{2}}{a^{2} \sin ^{2} \beta}+\frac{k^{2}}{b^{2}}+\frac{l^{2}}{c^{2} \sin ^{2} \beta}-\frac{2 h l \cos \beta}{a c \sin ^{2} \beta}
$$

Where symbols have their usual meanings and already been explained in our previous papers $^{14,22-24}$.

\begin{tabular}{|c|c|c|c|c|c|c|}
\hline S. No. & Samples & $\begin{array}{c}\text { Lattice } \\
\text { Parametera }(\AA)\end{array}$ & $\begin{array}{c}\text { Lattice } \\
\text { Parameterb }(\AA)\end{array}$ & $\begin{array}{c}\text { Lattice } \\
\text { Parameterc }(\AA)\end{array}$ & $\beta$ (degree) & $\begin{array}{c}\text { Unit Cell } \\
\text { VolumeV (Å3) }\end{array}$ \\
\hline 1 & $\mathrm{Na}_{2} \mathrm{Ti}_{6} \mathrm{O}_{13}$ & 15.5999 & 3.800 & 9.1600 & 99.10 & 543.001 \\
\hline 2 & $\mathrm{Na}_{2} \mathrm{Ti}_{5.96} \mathrm{Ni}_{0.04} \mathrm{O}_{13}$ & 15.5970 & 3.798 & 9.1560 & 98.89 & 542.377 \\
\hline 3 & $\mathrm{Na}_{2} \mathrm{Ti}_{5.92} \mathrm{Ni}_{0.08} \mathrm{O}_{13}$ & 15.5878 & 3.798 & 9.1350 & 98.80 & 541.133 \\
\hline 4 & $\mathrm{Na}_{2} \mathrm{Ti}_{5.88} \mathrm{Ni}_{0.12} \mathrm{O}_{13}$ & 15.5400 & 3.800 & 9.1110 & 98.71 & 538.023 \\
\hline
\end{tabular}

Table 1: Lattice parameters of pure and nickel doped 


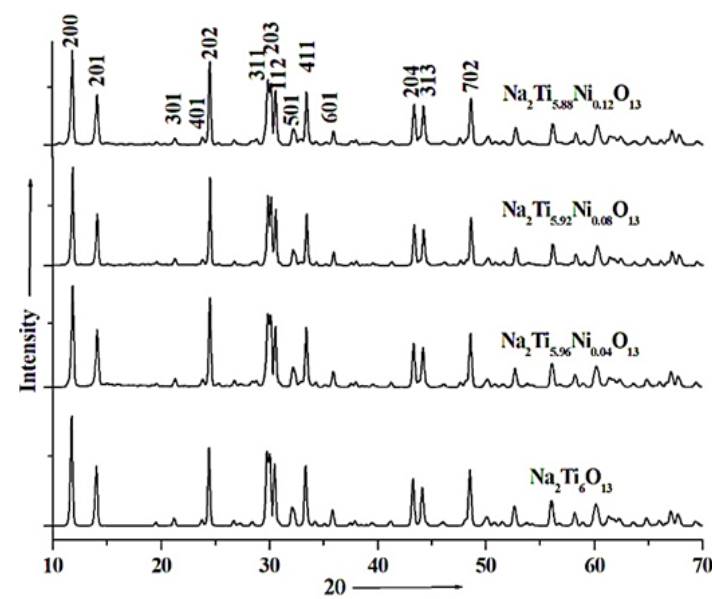

Fig. 1. XRD Analysis of pure and Ni doped NHT

It has been found that $\mathrm{a} \neq \mathrm{b} \neq \mathrm{c}$, and also $\alpha$ $=\gamma=90^{\circ} \neq \beta$, as the case should be for monoclinic structure, here the value of $\beta$ is decreasing on increasing the doping percentage of nickel. The unit volume cell gradually decreases on increasing the $\mathrm{Ni}$ in pure as shown in Table 1.

\section{FE-SEM Analysis}

Morphology of all synthesized materials have been done by field emission scanning electron microscopy (FE-SEM) at 10kV accelerating voltage. All the samples have been analyzed in secondary mode at various magnifications.

The morphological study showed that all the samples have rod shaped in micron range. It has also been confirmed that these samples have hexagonal structure.

Figures $2 \mathrm{a}, 2 \mathrm{~b}, 2 \mathrm{c}$ and $2 \mathrm{~d}$ show the SEM images (microstructures) of all synthesized samples as rod shaped and particle shape of all samples is hexagonal. Fig. $2 a$ is depicting SEM image of pure NHT and edge to edge distance of the particles lies between 0.1 to $0.25 \mu \mathrm{m}$ and length lies between 0.8 to $1.3 \mu \mathrm{m}$.

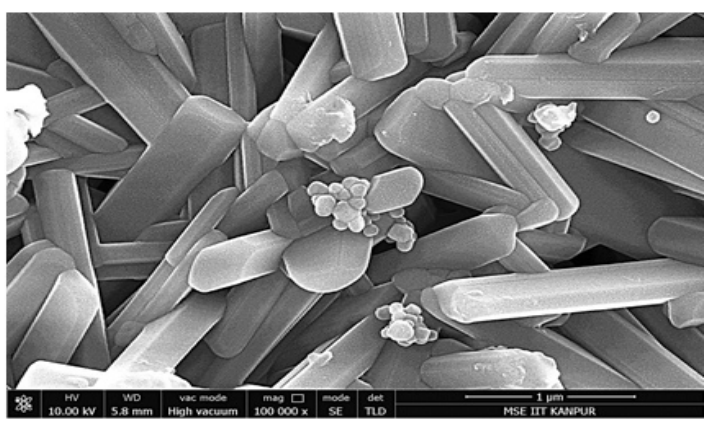

Fig. 2a. SEM image of Pure NHT

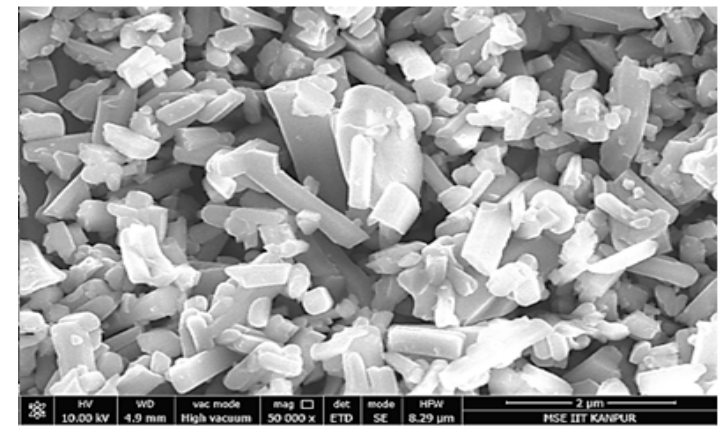

Fig. 2 b. SEM image of $4 \%$ Ni doped NHT

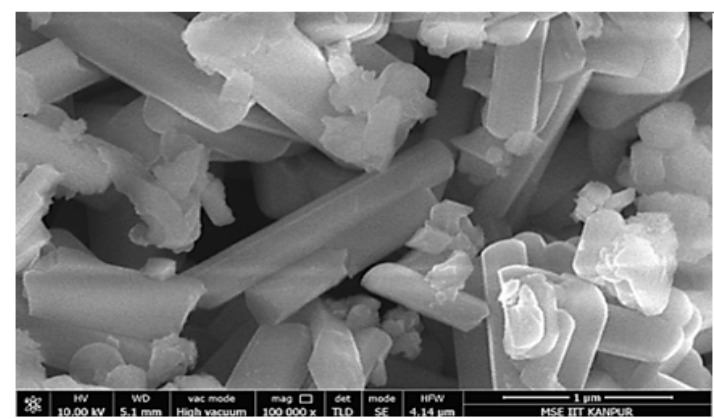

Fig. 2c. SEM image of $8 \% \mathrm{Ni}$ doped NHT

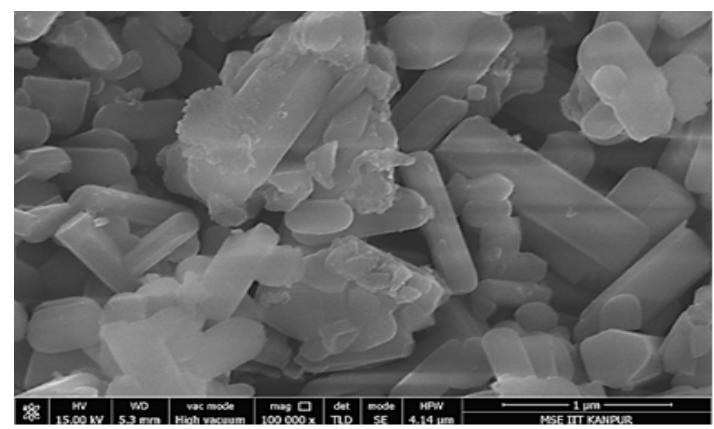

Fig. 2d. SEM image of $12 \%$ Ni doped NHT

Figures $2 \mathrm{~b}, 2 \mathrm{c}$, and $2 \mathrm{~d}$ show the SEM images of transition metal nickel doped NHT $\left(\mathrm{Na}_{2} \mathrm{Ti}_{6-\mathrm{x}} \mathrm{Ni}_{\mathrm{x}} \mathrm{O}_{13}\right)(\mathrm{x}=4 \%, 8 \%$, and $12 \%)$ and edge to edge distance of the particles lies between 0.1 to $0.25 \mu \mathrm{m}$ and length 0.7 to $1.2 \mu \mathrm{m}$. Average size of the doped samples is presented in Table 2 and they are also in rod shaped. The small change in the length of the rod has been observed, only because of the doping in pure sodium hexa-titanate. The most appropriate reason behind this is atomic radius of the dopant. Atomic radius of titanium is 215 pico-meter while atomic radius of nickel is 163 pico-meter. When nickel replaces the titanium ions, size of the samples also reduces due to the smaller atomic radius of nickel. 
Table 2: Particle size of pure and nickel doped Sodium hexa-titanate

\begin{tabular}{ccc}
\hline S. No. & Samples & Average Length of Rod \\
\hline 1 & $\mathrm{Na}_{2} \mathrm{Ti}_{6} \mathrm{O}_{13}$ & $1.20 \mu \mathrm{m}$ \\
2 & $\mathrm{Na}_{2} \mathrm{Ti}_{5.96} \mathrm{Ni}_{0.04} \mathrm{O}_{13}$ & $1.10 \mu \mathrm{m}$ \\
3 & $\mathrm{Na}_{2} \mathrm{Ti}_{5.92} \mathrm{Ni}_{0.08} \mathrm{O}_{13}$ & $1.08 \mu \mathrm{m}$ \\
4 & $\mathrm{Na}_{2} \mathrm{Ti}_{5.88} \mathrm{Ni}_{0.12} \mathrm{O}_{13}$ & $1.00 \mu \mathrm{m}$ \\
\hline
\end{tabular}

\section{DSC Analysis}

The rate of change of heat in energy has been measured using differential scanning calorimetry (DSC), with function of temperature. DSC plot gives the information that at which temperature materials release its heat, known as exothermic peak.

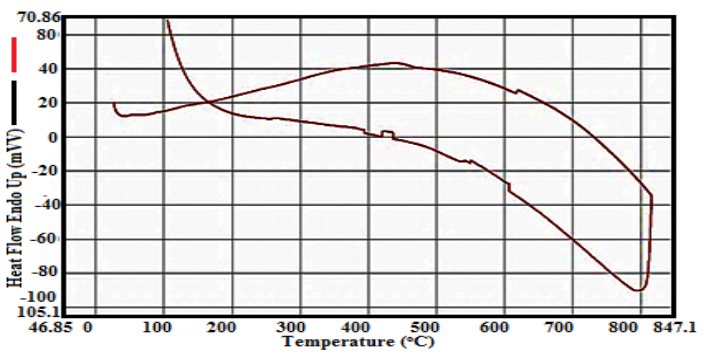

Fig. 3a. DSC analysis of pure NHT
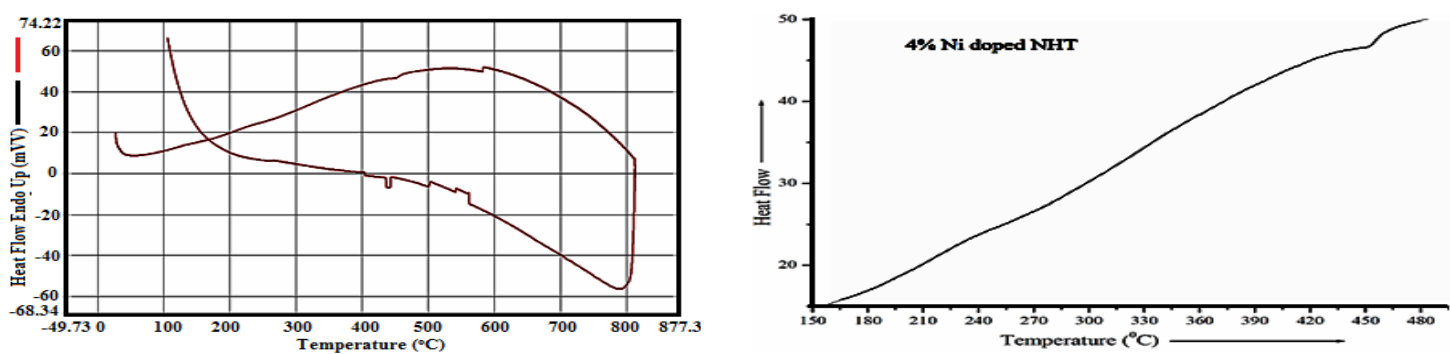

Fig. 3b. DSC analysis of $4 \% \mathrm{Ni}$ doped NHT
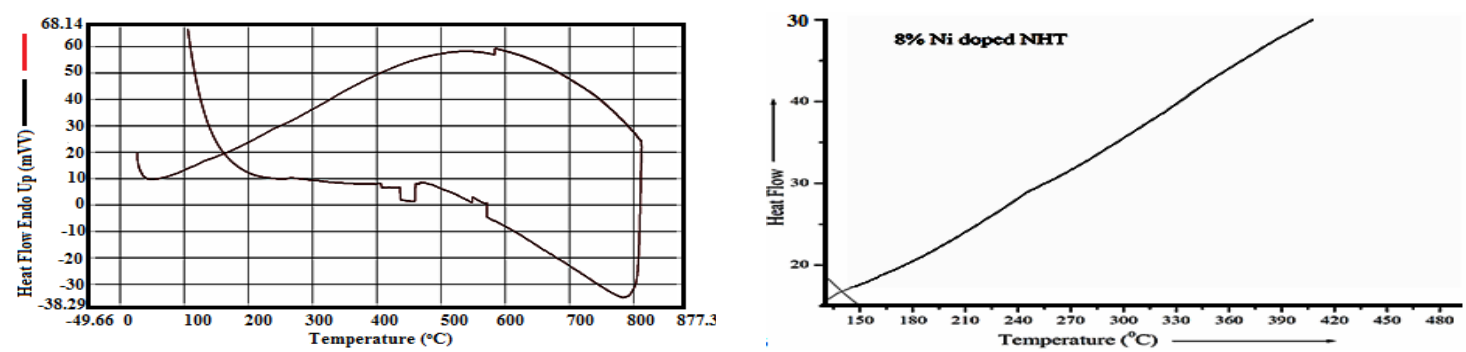

Fig. 3c. DSC analysis of $8 \% \mathrm{Ni}$ doped NHT
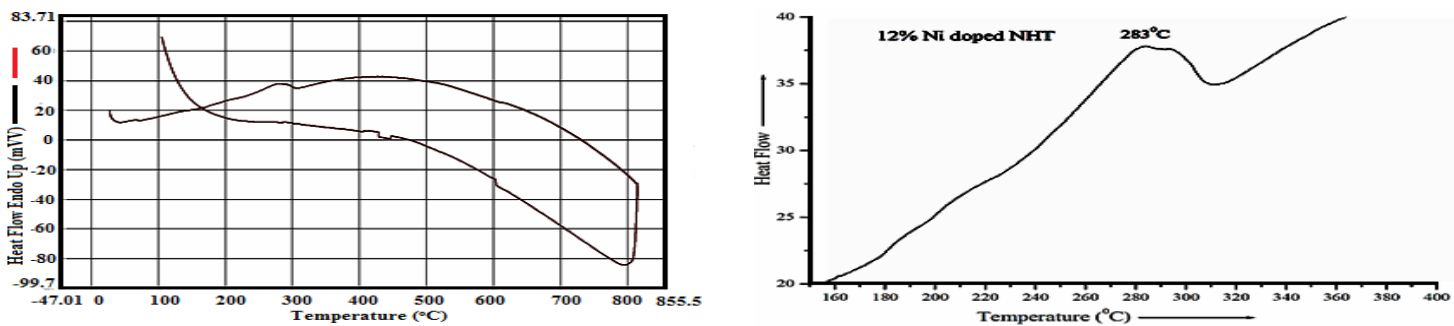

Fig. 3d. DSC analysis of $12 \% \mathrm{Ni}$ doped NHT 


\section{CONCLUSION}

The alkali titanate, sodium hexa-titanate (pure and $\mathrm{Ni}$ doped) were synthesized using conventional solid state reaction method and found that these materials having monoclinic structure and single-phase formation.

Morphological study of all samples shows rod shaped structure and it has been found that on increasing $\mathrm{Ni}$ dopant in pure sodium hexa-titanate the particle size decreases.

The most probable reason behind this is replacement of titanium with nickel.

The thermal study of all prepared samples confirms that on increasing the doping percentage at $12 \%$ molar concentration an exothermic is obtained 283.

\section{ACKNOWLEDGMENT}

One of the author is thankful to TEQIP-III of REC Ambedkar Nagar for providing the financial assistanceship for the project.

\section{Conflict of interest}

There is no conflict of interest.

\section{REFERENCES}

1. Kudo, A.; Kondo, T. J. Mater. Chem., 1997, 7, 777-780.

2. Shibata, M.; Kudo, A.; Tanaka, A.; Onishi, T. J. Catal., 1990, 124, 541-547.

3. Anderson, S.; Wadsley, A.D. Acta Chem. Scand., 1961, 15, 663-669.

4. Siddiqui, M.A.; Chandel, V.S.; Azam, A.; Shariq, M. Mater. Sci., 2013, 31, 555-560.

5. Sasaki, T.; Watanabe,M.;Yu, K.;Fujiki, Y.Inorg. Chem., 1985, 24, 2265-2271.

6. Cid-Dresdner, H.; Buerger, M. J.Z. Kristallogr., 1962, 117, 411-430.

7. Sugita, M.; Tsuji, M.; Abe, M.Bull.Chem. Soc. Jpn., 1978, 63, 1990.

8. Berry, K. L.; Aftandilian, V. D.; Gilbert, W. W. J. Inorg. Nucl. Chem., 1960, 4, 231.

9. Kikkawa; Koizumi, M. Else. Publ. Co., 1988. 83-90.

10. Fujishiro, Y.; Uchida, S.; Sato, T. Int. J. Inorg. Mater., 1999, 1, 67.

11. Dominko, R.; Baudrin, E.; Umek, P. Electrochem.Commun., 2006, 8, 673-677.

12. Alam, N.; Chandel, V. S.; Azam, A. Journal of Science and Arts., 2019, 2, 485-492.

13. Catti, M.; Pinus I.; Scherillo, A. J. Solid-State Chem., 2013, 205, 64-70.

14. Kanchanawarin, J.; Limphirat, W.; Promchana, P.; Sooknoi, T.; Maluangnont, T.; Simalaotao, K.; Boonchun, A.; Reunchan, P.; Limpijumnong, S.; Thienprasert, J.T. J. Appl. Phys., 2018, 124, 155101.

15. Sauvet, A. L.; Baliteau, S.; Lopez, C.; Fabry, P. J. Solid State Chem., 2004, 177, 4508-4515.

16. Stengl, V.;Bakardjieva, S.; Subrt, J.; Vecernı'kova, E.; Szatmary, L.;Klementova, M.; Balek, V. Appl. Catal. B., 2005, 63, 20-30.

17. Cardoso, V.A.; Nunes, L.M.; Santos, J. C. O.; Santos, I. M. G.; Conceição, M. M.; Santos Jr, J. R.; Souza, A. G. J. Therm. Anal. Calorim., 2005, 79, 361-365.
18. Umek, P.; Korosec, R.C.; Jancar, B.; Dominko, R.; Arcon, D. J. Nanosci. Nanotechnol., 2007, 7, 3502-3508.

19. Razali, M.H.; Noor, A.F.M.; Mohamed, A.R.; Sreekantan, S. J. Nanomater., 2012, 1-10.

20. Le Granvalet-Mancini M. Eur. J. Solid State Inorg. Chem., 1994, 31, 767.

21. Tournoux, M.; Marchand, R.; Brohan, L. Prog. Solid St. Chem., 1986, 17, 33-52.

22. Siddiqui, M. A.; Chandel, V. S.; Shariq, M.; Azam, A., J. Mat. Sci.: Mats in Elect., 2013, 24(12), 4725-4731.

23. Siddiqui, M. A.; Chandel, V.S.; Azam, A.; Applied Surface Science., 2012, 258(19), 7354 - 7358.

24. Siddiqui, M. A.; Chandel, V. S.; Azam, A.; Asian J. of Appl.Sci., 2012, 5(6), 423-430.

25. Vikram, S. V.; Maurya, D.; Phase, D. M.; Chandel, V. S., J. Mat. Sci.: Mats in Elect., 2012, 23, 718-727.

26. Vikram, S. V.; Phase, D.M.; Chandel, V.S.; J. of Alloys and Comp., 2010, 489(2), 700-707.

27. Vikram, S. V.; Phase, D. M.; Chandel, V.S.; J. Mat. Sci.: Mats in Elect., 2010, 21(9), 902-905.

28. Vikram, S. V.; Maurya, D.; Chandel, V. S.; Mat. Sci. Poland., 2009, 27(1),193-199.

29. Vikram, S. V.; Maurya, D.; Chandel, V. S.; J. of Alloys and Comp., 2009, 478(1-2), 398-403.

30. Siddiqui, M. A.; Chandel, V. S.; Azam, A.; Pure Appl. and Ind.Phys., 2012, 2(2), 132-135.

31. Alam, N.; Khatoon, T.; Chandel, V. S.; Azam, A.; Indian Journal of Science and Technology., 2019, 12, 1-5.

32. Alam, N.; Khatoon, T.; Chandel, V. S.; Azam, A.; Tripathi, S.; Rashmi; Shariq, M. Inter. Conference on Computational and Characterization Techniques in Engineering \& Sciences (CCTES), Lucknow, India., 2018, 291-294.

33. Alam, N.; Khatoon, T.; Chandel, V.S.; Azam, A.; J. of Phys.: Conf. Ser., 2020, 1495, 012034. 